\title{
Methylene blue revisited: Management of hypotension in a pediatric patient with bacterial endocarditis
}

\author{
Katherine Taylor, BMed (Hons), BA, FANZCA, and Helen Holtby, MB, BS, FRCPC, Toronto, Ontario, Canada
}

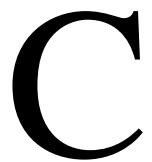

urrent theories on nitric oxide and sepsis hypothesize that selective inhibition of guanylate cyclase may be beneficial in septic shock. ${ }^{1}$ We present a case of refractory hypotension in a pediatric patient with native mitral valve endocarditis with cerebral complications in whom methylene blue was less effective than previously described. ${ }^{2,3}$

\section{Clinical Summary}

A 10-year-old girl, weighing $32 \mathrm{~kg}$, with no medical history was transferred from a regional center with Staphylococcal aureus native mitral valve endocarditis complicated by cerebral infarction and hemorrhage in both frontal lobes, the right thalamus, and possibly the left caudate nucleus and thalamus. She deteriorated day 2 of admission with chorda rupture, and an emergency mitral valve operation was indicated.

Standard anesthesia was administered. Preanesthesia inotropes were dopamine $10 \mu \mathrm{g} \cdot \mathrm{kg}^{-1} \cdot \min ^{-1}$ and epinephrine $0.5 \mu \mathrm{g}$. $\mathrm{kg}^{-1} \cdot \min ^{-1}$. A bolus dose of $2 \mathrm{mg} / \mathrm{kg}$ of methylene blue was given. On commencement of cardiopulmonary bypass, a further 2 $\mathrm{mg} / \mathrm{kg}$ and an infusion of $1 \mathrm{mg} \cdot \mathrm{kg}^{-1} \cdot \mathrm{h}^{-1}$ of methylene blue was commenced. An abscess around the mitral valve annulus was resected and replaced with a porcine valve. The dilated left atrium and ventricle were reinforced with a bovine pericardial patch.

During bypass, mean arterial pressure was maintained between 30 and $40 \mathrm{~mm} \mathrm{Hg}$. Cerebral oximetry ranged from $76 \%$ to $93 \%$ prebypass during methylene blue infusion and from $66 \%$ to $82 \%$ during bypass. Surprisingly, methylene blue did not seem to affect oximetry readings. The CPB time was 133 minutes, and the aortic crossclamp time was 115 minutes. Weaning from bypass required epinephrine 0.05 to $0.1 \mu \mathrm{g} \cdot \mathrm{kg}^{-1} \cdot \mathrm{min}^{-1}$, norepinephrine $0.1 \mu \mathrm{g} \cdot \mathrm{kg}^{-1}$. $\min ^{-1}$, vasopressin 0.0001 to $0.0003 \mu \mathrm{g} \cdot \mathrm{kg}^{-1} \cdot \min ^{-1}$, milrinone $0.33 \mu \mathrm{g} \cdot \mathrm{kg}^{-1} \cdot \mathrm{min}^{-1}$, and methylene blue infusion at $1 \mathrm{mg} \cdot$ $\mathrm{kg}^{-1} \cdot \mathrm{h}^{-1}$ to achieve a systolic arterial pressure of 70 to $80 \mathrm{~mm} \mathrm{Hg}$ and diastolic pressure range of 30 to $50 \mathrm{~mm} \mathrm{Hg}$.

The patient was transferred to the critical care unit and extubated 6 days later. The methylene blue infusion was ceased on arrival to the unit. Epinephrine and norepinephrine were ceased the

\footnotetext{
From the Department of Anesthesia, The Hospital for Sick Children, Toronto, Ontario, Canada,

Received for publication Dec 15, 2004; accepted for publication Jan 3, 2005.

Address for reprints: Katherine Taylor, MD, Department of Anesthesia, The Hospital for Sick Children, 555 University Ave, Toronto, Ontario M5G 1X8, Canada (E-mail: ktaylor406@hotmail.com).

J Thorac Cardiovasc Surg 2005;130:566

$0022-5223 / \$ 30.00$

Copyright $\odot 2005$ by The American Association for Thoracic Surgery

doi:10.1016/j.jtcvs.2005.01.001
}

day after surgery, vasopressin was ceased on postoperative day 2 , and milrinone was ceased on day 8 .

\section{Discussion}

Septic shock is characterized by arterial hypotension associated with peripheral vasodilation and the early development of myocardial depression. Nitric oxide has been implicated in these derangements. ${ }^{2,4}$ Exposure to endotoxin and cytokines can trigger a de novo synthesis of the inducible, calcium-dependent isoform of nitric oxide synthase. Methylene blue inhibits this process by decreasing intracellular cyclic guanosine monophosphate concentrations through guanylate cyclase inhibition, thus blocking its vasodilator properties. ${ }^{1}$ Methylene blue increases arterial pressure, systemic vascular resistance, and left ventricular stroke work but does not increase cardiac output, oxygen delivery, or oxygen consumption. ${ }^{4}$ The release of nitric oxide may be beneficial by increasing blood flow to ischemic areas, scavenging oxygen free radicals, and exerting microbiocidal properties. $^{2}$

\section{Conclusion}

A literature review revealed sporadic case reports and 1 prospective clinical trial in adults using methylene blue to treat the refractory hypotension in septic shock. A retrospective review estimated a mortality risk of $66.3 \%$ in 1 series for adult patients with infective endocarditis who had experienced cerebral infarction within 24 hours preceding cardiac surgery. ${ }^{5}$ We present a pediatric case in which refractory hypotension from infective endocarditis was treated with methylene blue. The obvious clinical improvement using methylene blue in a previously published case report was not evident in this case, but her postoperative course was relatively benign. ${ }^{2,3}$ Improvement of blood pressure does not necessarily correlate with improved tissue perfusion in the patient with sepsis, and we suggest this case report as further justification for larger scientifically controlled trials investigating methylene blue as an agent for refractory hypotension.

\section{References}

1. Driscoll W, Thurin S, Carrion V, Steinhorn R, Morin FCI. Effect of methylene blue on refractory neonatal hypotension. J Pediatr. 1996; 129:904-8.

2. Grayling M, Deakin C. Methylene blue during cardiopulmonary bypass to treat refractory hypotension in septic endocarditis. $J$ Thorac Cardiovasc Surg. 2003;125:426-7.

3. Sparicio D, Landoni G, Pappalardo F, Crivellari M, Cerchierini E, Marino G, et al. Methylene blue for lithium induced refractory hypotension in off-pump coronary artery bypass graft: report of two cases. J Thorac Cardiovasc Surg. 2004;127:592-3.

4. Preiser J-C, Lejeune P, Roman A, Carlier E, De Backer D, Leeman M, et al. Methylene blue administration in septic shock: a clinical trial. Crit Care Med. 1995;23:259-64.

5. Eishi K, Kawazoe K, Kuriyama Y, Kitoh Y, Kawashima Y, Omae T. Surgical management of infective endocarditis associated with cerebral complications. J Thorac Cardiovasc Surg. 1995;110:1745-55. 